\title{
ANALISIS PENGARUH PROFITABILITAS LIKUIDITAS DAN PERTUMBUHAN PERUSAHAAN TERHADAP KEBIJAKAN UTANG SERTA DAMPAKNYA TERHADAP TARIF PAJAK EFEKTIF
}

\author{
Sri Sarwoasih dan Indarto
}

indarto@usm.ac.id

Program Studi Magister Manajemen, Universitas Semarang, Semarang, Indonesia

\section{Info Artikel}

Sejarah Artikel:

Diterima

Disetujui

Dipublikasikan

Keywords:

Asset Growth;

Current Ratio;

Debt to Equity Ratio;

Effective Tax Rate;

Return on Asset

\begin{abstract}
Abstrak
Penelitian ini bertujuan untuk mengetahui pengaruh profitabilitas yang diproksikan dengan return on asset, pengaruh likuiditas yang diproksikan dengan current ratio serta pengaruh pertumbuhan perusahaan yang diproksikan dengan asset growth dan sales growth terhadap effective tax rate dengan debt to equity ratio sebagai variable intervening dan untuk mengetahui pengaruh return on asset dan sales growth secara langsung terhadap effective tax rate. Jenis data yang digunakan berupa data kuantitatif dengan metode purposive sampling, sampel penelitian adalah perusahaan manufaktur yang terdaftar di Bursa Efek Indonesia tahun 2014-2016 sejumlah 108 sampel.

Hasil uji hipotesis menyatakan return on asset dan current ratio berpengaruh signifikan terhadap debt to equity ratio, asset growth dan sales growth tidak berpengaruh signifikan terhadap debt to equity ratio, debt to equity ratio, return on asset, dan sales growth berpengaruh signifikan terhadap effective tax rate. Hasil sobel test model 1 : debt to equity ratio berhasil memediasi return on asset dan effective tax rate, Model 2 : debt to equity ratio tidak berhasil memediasi sales growth dan effective tax rate.
\end{abstract}

\section{ANALYSIS OF THE EFFECT OF PROFITABILITY, LIQUIDITY AND GROWTH OF THE COMPANY TO DEBT POLICY AND THE IMPACT OF EFFECTIVE TAX RATES}


108.

Hypothesis test result : return on asset and current ratio has significant effect to debt to equity ratio, asset growth and sales growth has not significant effect on debt to equity ratio, debt to equity ratio, return on asset and sales growth has a significant effect on effective tax rate. The results of the sobel test model 1: debt to equity ratio succeed in mediating return on assets and effective tax rate, Model 2: debt to equity ratio did not succeed in mediating sales growth and effective tax rate. 


\section{PENDAHULUAN}

Struktur modal adalah perimbangan atau perbandingan antara total utang terhadap modal sendiri (Riyanto, 2001). Struktur modal merupakan hal yang penting dalam pengambilan keputusan mengenai pembelajaran perusahaan. Keputusan modal secara langsung berpengaruh terhadap besarnya risiko yang ditanggung oleh pemegang saham serta besarnya tingkat pengembalian atau keuntungan yang diharapkan (Brigham dan Houston, 2001). Selain itu keputusan struktur modal akan berpengaruh terhadap besarnya manfaat pajak yang akan dinikmati oleh perusahaan karena membayar bunga, dimana bunga merupakan beban yang dapat mengurangi besarnya pajak.

Teori struktur modal yang pertama yaitu dikeluarkan oleh Franco Modigliani dan Merton H Miller pada tahun 1958 pada tulisan The Cost Of Capital Corporate Finance and The Theory Of Invesment yang dikenal dengan teori MM menyatakan bahwa perusahaan yang menggunakan utang dapat digunakan untuk mengurangi pajak sehingga dapat menaikkan nilai perusahaan (Teddy, 2008). Penelitian mengenai pengaruh utang terhadap besarnya pajak umumnya dilakukan pada negara-negara maju, sedangkan penelitian pada negara berkembang masih jarang dilakukan (Pandey, 2003). Selain itu, banyak faktor yang berpengaruh terhadap keputusan struktur modal, secara umum terdiri dari faktor stabilitas penjualan, struktur aktiva, tingkat pertumbuhan, profitabilitas, pajak, pengendalian, sikap manajemen, sikap pemberi pinjaman, kondisi pasar, kondisi internal perusahaan dan fleksibilitas keuangan (Brigham dan Houston, 2001).

Tarif pajak efektif perusahaan sering digunakan sebagai salah satu acuan oleh para pembuat keputusan dan pihak-pihak yang berkepentingan untuk membuat kebijakan dalam perusahaan dan memuat kesimpulan sistem perpajakan pada perusahaan, salah satu cara untuk mengukur seberapa baik sebuah perusahaan mengelola pajaknya adalah dengan tarif efektifnya (Karayan, 2007). Tarif pajak efektif merupakan perbandingan antara beban pajak yang dibayar perusahaan dengan penghasilan sebelum pajak. Tarif pajak efektif sangat berguna untuk mengukur beban pajak yang sebenarnya. Tarif pajak efektif digunakan untuk mengetahui berapa bagian dari penghasilan yang sebenarnya di bayarkan untuk pajak dibandingkan dengan tarif pajak marginal. Tarif pajak marginal sebagian besar perusahaan di Amerika nilainya hampir sama sedangkan tarif pajak efektif antar perusahaan memiliki perbedaan yang signifikan (Desi, 2014).

Perdebatan antara tarif pajak dan tarif pajak efektif merupakan masalah yang sering muncul pada pajak perusahaan. Tarif pajak efektif digunakan untuk mengukur pajak yang dibayarkan sebagai proporsi dari pendapatan ekonomi sedangkan tarif pajak yang berlaku menunjukkan jumlah kewajiban pajak relatif terhadap penghasilan kena pajak. Ada beberapa faktor yang mempengaruhi perusahaan untuk membayar pajak, kemampuan memperoleh laba (profitabilitas) merupakan salah satunya. Namun dengan berlakunya sistem self-assesment dalam pemenuhan kewajiban perpajakan yang memberi kepercayaan kepada Wajib Pajak untuk menghitung, menyetor dan melaporkan pajaknya memberikan peluang kepada Wajib Pajak untuk mengurangi beban pajaknya dengan cara memperkecil laba sebelum pajak.

Salah satu upaya perencanaan pajak (tax planning) adalah dengan melakukan thin capitalization yaitu pendanaan dengan menggunakan utang yang lebih besar dibanding dengan modal saham. Dengan kata lain pendanaan dengan menggunakan modal asing 
lebih besar daripada modal sendiri. Karena bunga atas utang bisa dibiayakan dan mengurangi penghasilan kena pajak sedangkan deviden atas modal yang disetor oleh pemegang saham tidak menjadi komponen biaya atau pengurang dalam penghitungan penghasilan kena pajak. Sehingga praktek memilih utang sebagai alternatif pembiayaan lebih dipilih oleh Perusahaan daripada memperbesar modal dengan tujuan mengurangi beban pajak yang harus dibayar.

Pengaruh profitabilitas, likuiditas dan pertumbuhan perusahaan terhadap kebijakan utang (leverage) serta dampaknya terhadap tarif pajak efektif (effective tax rate) merupakan sesuatu yang menarik untuk diteliti. Respitasari (2015) menyebutkan bahwa return on asset (ROA) berpengaruh negatif signifikan terhadap DER, saat perusahaan meningkat keuntungannya maka akan menggunakan pertambahan labanya atau laba ditahan untuk kepentingan investasi daripada menggunakan modal pinjaman dari pihak eksternal. Rodiuguez dan Arias (2012) menyebutkan bahwa hubungan antara profitabilitas dan effektive tax rate bersifat langsung dan signifikan, perusahaan yang memiliki kemampuan memperoleh keuntungan harus mempersiapkan pajak yang akan dibayarkan sebesar pendapatan yang diperoleh. Return on asset (ROA) merupakan salah satu indikator bagi perusahaan dalam pencapaian laba (profitabilitas) perusahaan, dimana laba merupakan faktor penting dalam penentuan besaran tarif pajak efektif, jika laba tinggi maka Effective Tax Rate juga naik (Ardyansah,2014).

Likuiditas perusahaan merupakan salah satu faktor penting dalam menentukan struktur modal yang optimal, perusahaan yang memiliki likuiditas dalam hal ini current ratio yang tinggi menandakan bahwa perusahaan tersebut dapat menggunakan aset yang likuid sebagai sumber pembiayaan sehingga posisi likuiditas sebuah perusahaan memiliki hubungan negatif dengan rasio leverage (Putra, 2012).

Peningkatan aset yang diikuti peningkatan hasil operasi akan semakin menambah kepercayaan pihak luar terhadap perusahaan. Dengan meningkatnya kepercayaan pihak luar (kreditur) terhadap perusahaan, maka proporsi utang semakin besar daripada modal sendiri. Hal ini didasarkan pada keyakinan kreditur atas dana yang ditanamkan kedalam perusahaan dijamin oleh besarnya aset yang dimiliki perusahaan (Ang,1997). Menurut penelitian Sunarwi (2010) pertumbuhan aktiva (asset growth) berdampak positif tidak signifikan terhadap leverage (DER).

Perusahaan dengan tingkat pertumbuhan penjualan dan laba yang tinggi memiliki kecenderungan penggunaan utang sebagi sumber dana eksternal yang lebih besar dibandingkan perusahaan dengan tingkat pertumbuhan yang rendah (Mayangsari, 2001). Pertumbuhan penjualan yang tinggi selalu diikuti dengan peningkatan dana yang digunakan untuk pembiayaan ekspansi (Nugrahani, 2012).

Menurut Karayan dan Swenson (2007), bahwa untuk mengukur seberapa baik sebuah perusahaan mengelola pajaknya adalah dengan melihat tarif efektifnya. Dimana tarif pajak efektif adalah perbandingan antara pajak riil yang kita bayar dengan laba komersial sebelum pajak (Richardson dan Lanis, 2007). Tarif pajak efektif dipengaruhi oleh kebijakan utang perusahaan, yaitu meningkatnya biaya bunga utang menyebabkan berkurangnya jumlah pajak yang dibayarkan. Selain itu, tarif pajak efektif juga dipengaruhi oleh profitabilitas perusahaan. Sementara kebijakan utang atau leverage itu sendiri dipengaruhi oleh profitabilitas, likuiditas dan pertumbuhan perusahaan.

Penelitian ini menggunakan sampel perusahaan manufaktur yang terdaftar di Bursa Efek Indonesia ahun 2014-2016. Besarnya rata-rata keempat variabel independen (profitability, current ratio, asset growth dan sales growth) dan dua variabel dependen 
(DER dan Effective Tax Rate) pada perusahaan manufaktur yang terdaftar di Bursa Efek Indonesia ahun 2014-2016 dapat dilihat pada tabel berikut:

Tabel 1.1

Rata-rata ROA, CR, Asset Growth, Sales Growth, DER dan ETR pada Perusahaan Manufaktur yang terdaftar di Bursa Efek Indonesia selama Tahun 2014-2016

\begin{tabular}{|l|c|c|c|}
\hline \multicolumn{1}{|c|}{ Variabel } & $\mathbf{2 0 1 4}$ & $\mathbf{2 0 1 5}$ & $\mathbf{2 0 1 6}$ \\
\hline ROA & $10.08 \%$ & $10.51 \%$ & $11.28 \%$ \\
\hline Current Ratio & $314.92 \%$ & $257.48 \%$ & $280.49 \%$ \\
\hline Asset Growth & $13,82 \%$ & $15.18 \%$ & $17.58 \%$ \\
\hline Sales Growth & $16.15 \%$ & $10.49 \%$ & $10.48 \%$ \\
\hline DER & $90.59 \%$ & $98.44 \%$ & $81.20 \%$ \\
\hline Effektive Tax Rate & $31.18 \%$ & $28.25 \%$ & $27.54 \%$ \\
\hline
\end{tabular}

Sumber : data BEI, diolah 2017

\section{TELAAH PUSTAKA}

\section{PENGARUH RETURN ON ASSET (ROA) TERHADAP DEBT TO EQUITY RATIO (DER)}

Return on Asset (ROA) merupakan rasio profitabilitas yang digunakan untuk mengukur efektifitas perusahaan didalam menghasilkan keuntungan dengan memanfaatkan aset yang dimilikinya. Perusahaan yang memiliki profitabilitas cukup untuk membiayai operasionalnya sehingga tidak perlu menambah besaran utang dari perusahaan tersebut, karena semakin besar keuntungan perusahaan, semakin besar laba ditahan yang mampu digunakan dalam operasional perusahaan (Nugrahani, 2012).

Return on asset (ROA) merupakan rasio antara laba bersih setelah pajak (earning after tax) terhadap total investasi. Mengingat investasi perusahaan dalam bentuk aktiva (asset), maka ROA sering disebut juga dengan return on asset (ROA). Semakin tinggi ROA menunjukkan semakin baik kinerja perusahaan, karena dana yang diinvestasikan ke dalam aset dapat menghasilkan earning after tax (EAT) yang semakin tinggi (Ang, 1997).

Peningkatan laba perusahaan (profitabilitas) memiliki hubungan negatif dengan penambahan utang perusahaan ditunjukkan oleh penelitian yang dilakukan Kesuma (2009) dan Erdiana (2011). Hal ini didasari bahwa perusahaan dengan penjualan yang bertumbuh diharapkan akan diikuti dengan peningkatan laba (profitabilitas) sehingga laba yang ditahan (retained earning) juga meningkat. Dari laba ditahan ini apabila tidak digunakan untuk membayar deviden maka perusahaan cenderung menggunakan laba ditahan tersebut untuk menambah dana investasi dan tidak perlu menambah utang. Oleh karena itu, peningkatan laba perusahaan (profitability) memiliki hubungan negatif dengan penambahan utang perusahaan (Respitasari, 2015). Berdasarkan uraian tersebut maka dapat diajukan hipotesis pertama adalah sebagai berikut:

Hipotesis 1: Ada pengaruh yang negatif antara ROA terhadap struktur modal (DER) PENGARUH CURRENT RATIO (CR) TERHADAP DEBT TO EQUITY RATIO
(DER) 
Likuiditas perusahaan merupakan salah satu faktor penting dalam menentukan struktur modal yang optimal, perusahaan yang memiliki likuiditas dalam hal ini current ratio yang tinggi menandakan bahwa perusahaan tersebut dapat menggunakan aset yang likuid sebagai sumber pembiayaan sehingga posisi likuiditas sebuah perusahaan memiliki hubungan negatif dengan rasio leverage (Putra, 2012). Myers dan Rajan (1998) juga menyatakan bahwa ketika biaya agensi dari likuiditas tinggi maka kreditur luar membatasi jumlah pembiayaan utang yang tersedia bagi perusahaan. Oleh karena itu terdapat hubungan negatif antara likuiditas (Current Ratio) dengan Debt to Equity Ratio (DER). Hal ini juga sesuai dengan penelitian yang dilakukan oleh Putra (2012). Dimana Putra (2012) menunjukan bahwa likuiditas (Current Ratio) berpengaruh negatif signifikan terhadap debt to equity ratio (DER). Dari uraian diatas maka hipotesis kedua yang diajukan dalam penelitian ini adalah :

Hipotesis 2 : Ada pengaruh yang negatif antara Current Ratio terhadap struktur modal (DER)

\section{PENGARUH ASSET GROWTH (AG) TERHADAP DEBT TO EQUITY RATIO (DER)}

Damayanti (2013) menyatakan variabel asset growth mempunyai pengaruh yang signifikan dengan arah positif terhadap struktur modal. Semakin meningkatnya pertumbuhan perusahaan menyebabkan perusahaan membutuhkan penambahan modal. Sedangkan para kreditur dalam memberikan pinjaman cenderung melihat pertumbuhan perusahaan sebagai pertimbangannya, semakin tinggi pertumbuhan perusahaan samakin mudah perusahaan mendapatkan dana dalam bentuk utang.

Peningkatan aset yang diikuti peningkatan hasil operasi akan semakin menambah kepercayaan pihak luar terhadap perusahaan. Dengan meningkatnya kepercayaan pihak luar (kreditur) terhadap perusahaan, maka proporsi utang semakin besar daripada modal sendiri (Respitasari, 2015). Hal ini didasarkan pada keyakinan kreditur atas dana yang ditanamkan kedalam perusahaan dijamin oleh besarnya aset yang dimiliki perusahaan (Ang,1997). Menurut penelitian Sunarwi (2010) pertumbuhan aktiva (asset growth) berdampak positif tidak signifikan terhadap leverage (DER). Dari uraian diatas maka hipotesis ketiga yang diajukan dalam penelitian ini adalah :

Hipotesis 3: Ada pengaruh yang positif antara asset growth dengan leverage (DER).

\section{PENGARUH SALES GROWTH TERHADAP DEBT TO EQUITY RATIO (DER)}

Perusahaan dengan pertumbuhan penjualan yang stabil dapat lebih aman, lebih banyak memperoleh pinjaman dan lebih mampu menanggung beban yang lebih tinggi dibanding dengan perusahaan yang pertumbuhan penjualanannya tidak stabil. Perusahaan yang tumbuh dengan pesat lebih banyak membutuhkan dana sehingga dibutuhkan banyak dana eksternal (Nugrahani, 2012).

Perusahaan dengan tingkat pertumbuhan penjualan dan laba yang tinggi memiliki kecenderungan penggunaan utang sebagi sumber dana eksternal yang lebih besar dibandingkan perusahaan dengan tingkat pertumbuhan yang rendah (Mayangsari, 2001). Pertumbuhan penjualan yang tinggi selalu diikuti dengan peningkatan dana yang digunakan untuk pembiayaan ekspansi (Nugrahani, 2012).

Penelitian tentang pengaruh pertumbuhan penjualan (sales growth) dengan debt to equity ratio (DER) banyak dilakukan, diantaranya Kesuma (2009) yang menyatakan sales growth berpengaruh negatif signifikan terhadap leverage (DER) dan Ema (2012) menunjukan bahwa terdapat pengaruh positif signifikan antara pertumbuhan penjualan dan leverage. Sedangkan Nugrahani (2012) menyatakan bahwa terdapat hubungan 
positif tidak signifikan antara pertumbuhan penjualan dengan DER. Dari uraian diatas maka hipotesis keempat yang diajukan dalam penelitian ini adalah :

Hipotesis 4 : Ada pengaruh yang positif antara sales growth terhadap kebijakan pendanaan (DER)

\section{PENGARUH LEVERAGE (DER) TERHADAP EFFECTIVE TAX RATE (ETR)}

Leverage dalam pengertian bisnis mengacu pada penggunaan aset dan sumber dana oleh perusahaan dimana dalam penggunaan aset atau dana tersebut dimaksudkan untuk meningkatkan keuntungan atau profit perusahaan. Tingkat rasio yang tinggi berarti perusahaan menggunakan tingkat utang yang tinggi pula dan penggunaan tingkat utang ini dapat meningkatkan profitabilitas perusahaan namun disisi lain utang yang tinggi juga memiliki risiko yang besar (Roifah, 2015).

Rasio leverage dapat digunakan untuk menggambarkan kemampuan perusahaan dalam memenuhi kewajiban jangka panjangnya. Berkurangnya sumber pendanaan di perusahaan dapat memicu konflik antar prinsipal dan agen. Pihak prinsipal menginginkan laba yang besar dengan jumlah pajak yang kecil, sedang pihak manajemen masih mempertimbangkan ada kemungkinan bahwa pihak prinsipal tidak setuju dengan permintaan pendanaan dari sumber intern yang diajukan pihak manajemen untuk keperluan perusahaan, sehingga pihak manajemen (agen) menutupi kebutuhan pembiyaan perusahaan dengan melakukan utang. Dengan pertimbangan jika utang bertambah maka bertambah pula beban bunga utang, yang mengakibatkan laba bersih berkurang. Berkurangnya laba bersih menyebabkan menurunnya pajak yang dibayarkan yang artinya tarif pajak efektif menjadi lebih kecil (Respitasari, 2015).

Penelitian yang dilakukan Ardyansah (2014) menyatakan adanya hubungan negatif tidak signifikan antara debt to equity ratio (DER) dengan effective tax rate (ETR). Demikian pula, penelitian Richardson dan Lanis (2007) menyebutkan bahwa leverage (DER) berpengaruh negatif signifikan terhadap effective tax rate (ETR). Dari uraian diatas maka hipotesis kelima yang diajukan dalam penelitian ini adalah :

Hipotesis 5: Leverage berpengaruh negatif terhadap Effective Tax Rate (ETR)

\section{PENGARUH RETURN ON ASSET (ROA) TERHADAP EFFECTIVE TAX RATE (ETR) \\ Return on asset (ROA) merupakan rasio yang menggambarkan kemampuan} perusahaan untuk menghasilkan laba dengan menggunakan aset yang dimiliki. Aset suatu perusahaan didanai oleh pemegang saham dan kreditur sehingga aset tersebut akan menjadi modal kerja bagi perusahaan dalam melakukan usahanya. Perusahaan yang memiliki kemampuan untuk memperoleh laba yang tinggi harus mempersiapkan pajak yang akan dibayarkan sebesar persentase tertentu yang telah ditetapkan dari laba yang diperoleh (Putri, 2016).

Salah satu indikator bagi perusahaan dalam pencapaian laba perusahaan, jika laba tinggi maka effective tax rate juga naik. Meningkatnya profitabilitas suatu perusahaan dapat disebabkan oleh meningkatnya kapasitas perusahaan atau sumber pendanaan dalam menjalankan aktivitas bisnis (Natalia, 2012). Perusahaan yang memiliki kemampuan untuk memperoleh keuntungan harus mempersiapkan pajak yang akan dibayarkan sebesar pendapatan yang diperoleh. Ini sejalan dengan penelitian yang dilakukan Hanum (2013) yang menyebutkan profitabilitas yang diproksikan dengan return on asset (ROA) memberi pengaruh positif terhadap tarif pajak efektif (effective tax rate). Dari pernyataan di atas maka hipotesis keenam yang diajukan yaitu: 
Hipotesis 6: Profitability (ROA) berpengaruh positif terhadap Effective Tax Rate (ETR).

\section{Kerangka Pemikiran Teoritis}

Pengaruh profitabilitas, likuiditas, pertumbuhan asset dan pertumbuhan penjualan terhadap kebijakan utang (leverage) serta pengaruh leverage, pengaruh profitabilitas dan pengaruh pertumbuhan penjualan secara langsung terhadap tarif pajak efektif dapat digambarkan dalam kerangka pemikiran teoritis sebagai berikut :

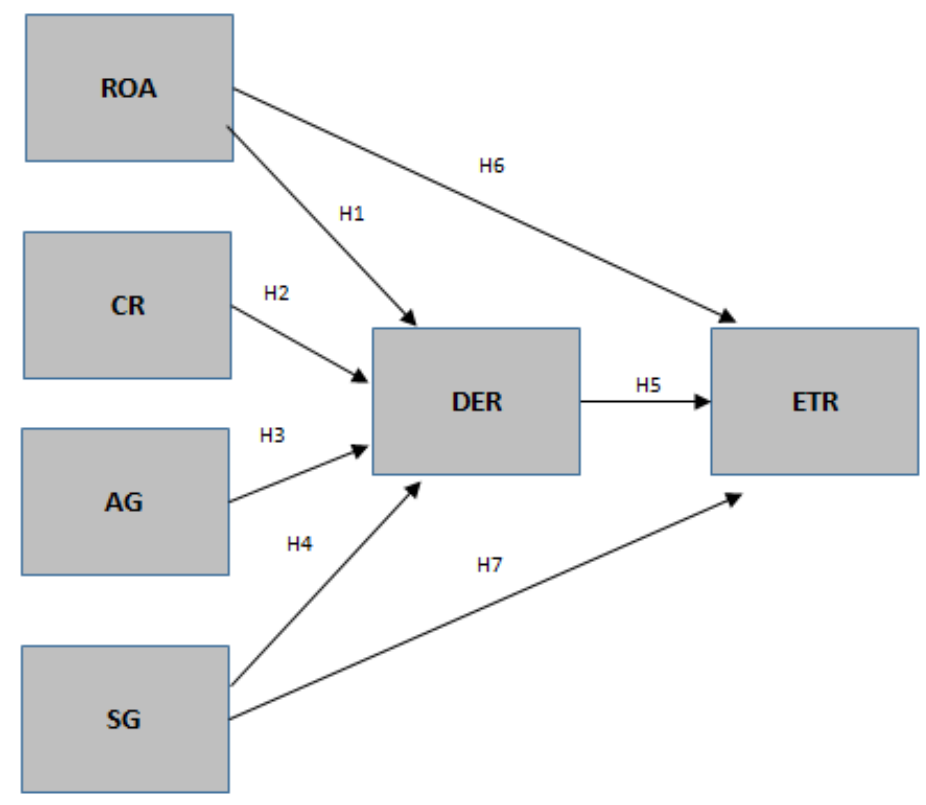

Gambar 1.1

Keterangan :

\section{Kerangka Pemikiran Teoritis}

$\begin{array}{ll}\text { ROA } & =\text { Return on Asset } \\ \text { CR } & =\text { Curent Ratio } \\ \text { AG } & =\text { Asset Growth } \\ \text { SG } & =\text { Sales Growth } \\ \text { DER } & =\text { Debt to Equity Ratio } \\ \text { ETR } & =\text { Effective Tax Rate }\end{array}$

\section{METODE}

Penelitian ini adalah penelitian kuantitatif yang menggunakan data sekunder berupa laporan keuangan dari perusahaan manufaktur yang terdaftar di Bursa Efek Indonesia pada periode penelitian Tahun 2014 sampai dengan 2016.

Populasi dalam penelitian ini adalah 153perusahaan manufaktur yang terdaftar di Bursa Efek Indonesia pada periode Tahun 2014-2016. Teknik pengambilan sampel penelitian menggunakan non random sampling dengan metode purposive sampling dengan pengambilan sampel yang didasarkan pada beberapa kriteria tertentu.

Berdasarkan kriteria yang telah ditetapkan diperoleh sampel penelitian penelitian sebagai berikut : 
Tabel 1.2

Distribusi Data Penelitian

\begin{tabular}{|l|c|}
\hline \multicolumn{1}{|c|}{ Uraian } & Jumlah \\
\hline Perusahaan Manufaktur & 153 \\
\hline Kebijakan utang & 116 \\
\hline Bayar Pajak & 109 \\
\hline $\begin{array}{l}\text { Mempunyai data laporan keuangan lengkap } \\
\text { pada semua variabel ( CR,AG, SG positif) }\end{array}$ & 36 \\
\hline Rentang penelitian & 3 \\
\hline Total Data Penelitian & 108 \\
\hline
\end{tabular}

\section{Definisi Operasional Variabel}

Definisi operasional variabel penelitian dapat ditunjukkan dalam tabel sebagai berikut :

Tabel 1.3

Definisi Operasional Variabel

\begin{tabular}{|c|c|c|c|c|}
\hline No & Variabel & Definisi & $\begin{array}{c}\text { Skala } \\
\text { Pengukuran }\end{array}$ & Pengukuran \\
\hline 1. & $\mathrm{ROA}$ & $\begin{array}{l}\text { Rasio antara laba } \\
\text { Bersih setelah pajak } \\
\text { (earning after tax- } \\
\text { EAT) terhadap total } \\
\text { asset }\end{array}$ & Rasio & $\frac{\text { EAT }}{\text { Total Asset }}$ \\
\hline 2. & $\begin{array}{l}\text { Current } \\
\text { Ratio }\end{array}$ & $\begin{array}{l}\text { Rasio antara curent } \\
\text { asset/ curent liabilities }\end{array}$ & Rasio & $\begin{array}{l}\text { Current asset } \\
\text { current liabilities }\end{array}$ \\
\hline 3. & $\begin{array}{l}\text { Asset } \\
\text { Growth }\end{array}$ & $\begin{array}{l}\text { Rasio antara total } \\
\text { asset periode } \\
\text { sekarang (Assett) } \\
\text { minus periaode } \\
\text { sebelumnya (Assett- } \\
\text { 1) terhadap total asset } \\
\text { Periode sebelumnya } \\
\text { (Assett-1) }\end{array}$ & Rasio & $\frac{\text { Asset }_{\mathrm{t}}-\text { Asset }_{\mathrm{t}-1}}{\text { Asset }_{\mathrm{t}-1}}$ \\
\hline 4. & $\begin{array}{l}\text { Sales } \\
\text { Growth }\end{array}$ & $\begin{array}{l}\text { Rasio antara total } \\
\text { Penjualan periode } \\
\text { sekarang (Penjualant) } \\
\text { minus periode } \\
\text { sebelumnya (Penjualant- } \\
\text { 1) terhadap total } \\
\text { penjualan } \\
\text { Periode sebelumnya } \\
\text { (Penjualant-1) }\end{array}$ & Rasio & $\begin{array}{l}\text { Net }_{\text {Sales }}-\text { Net } \\
\text { Sales }_{t-1} \\
\text { Net Sales }_{t-1}\end{array}$ \\
\hline 5. & Leverage & Rasio antara total & Rasio & Total Debt \\
\hline
\end{tabular}




\begin{tabular}{|c|c|c|c|c|}
\hline & (DER) & $\begin{array}{l}\text { debt terhadap } \\
\text { shareholder equity }\end{array}$ & & $\begin{array}{l}\text { Shareholder } \\
\text { Equity }\end{array}$ \\
\hline 6. & $\begin{array}{l}\text { Effective } \\
\text { Tax Rate } \\
\text { (ETR) }\end{array}$ & $\begin{array}{l}\text { Rasio antara biaya pajak } \\
\text { tahun berjalan terhadap } \\
\text { pretax income }\end{array}$ & Rasio & $\frac{\text { Biaya Pajak }}{\text { Pre Tax Income }}$ \\
\hline
\end{tabular}

Metode Analisis

Untuk menguji kekuatan variabel penentu yang pertama (ROA, current ratio, asset growth dan sales growth) terhadap leverage (DER) dan variable penentu kedua (ROA, sales growth dan leverage / DER) terhadap Effective Tax Rate (ETR) maka model panel data dalam penelitian ini dirumuskan sebagai berikut :

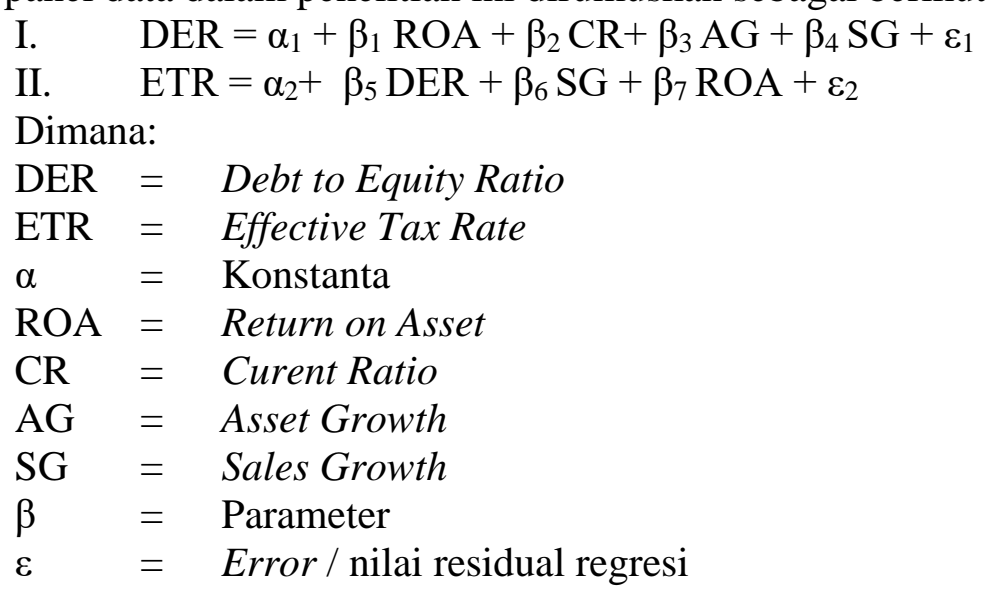

\section{HASIL DAN PEMBAHASAN}

Hasil Uji Normalitas dilakukan dengan Uji Kolmogorov-Smirnov dan nilai Asymp. Sig sebesar 0.200. Nilai uji normalitas yaitu signifikansi (Asymp. Sig.) $0.200>$ 0,05 , berarti bahwa data variabel-variabel tersebut berdistribusi secara normal, sehingga layak untuk dilakukan penelitian selanjutnya. Hasil Uji Multikolinearitas memiliki nilai tolerance diatas nilai 0,10 atau mendekati nilai 1 dan hasil perhitungan nilai Variance Inflation Factor (VIF) juga menunjukkan tidak ada variabel independen yang memiliki nilai VIF lebih dari 10. Hal ini berarti bahwa variabel-variabel independen yang digunakan dalam penelitian ini menunjukkan tidak adanya gejala multikolinieritas antar variabel independen dalam model regresi.

Hasil pengujian Heteroskedastisitas bahwa nilai signifikansi dari seluruh variabel mempunyai nilai lebih dari 0,05. Dengan demikian dapat disimpulkan bahwa tidak terjadi masalah heteroskedastisitas pada model regresi, sehingga model regresi layak untuk digunakan dalam melakukan pengujian. Hasil pengujian Autokorelasi nilai Durbin-Watson sebesar 1.781 dengan nilai dL sebesar 1,590 dan dU sebesar 1,784. Maka nilai dL < dU dan DW < 5-dU yaitu 1,590 < 1,784 dan 1.781 < 3,216. Dari nilai tersebut menunjukkan bahwa model regresi tidak terjadi autokorelasi. 
Tabel 1.4

Hasil Uji Path Analysis

\begin{tabular}{|l|r|r|r|r|r|l|}
\hline & \multicolumn{2}{|c|}{$\begin{array}{c}\text { Unstandardized } \\
\text { Coefficients }\end{array}$} & $\begin{array}{r}\text { Standardized } \\
\text { Coefficients }\end{array}$ & \multirow{2}{*}{$\mathrm{t}$} & \multirow{2}{*}{ Sig } & \multirow{2}{*}{ Ket } \\
\cline { 2 - 4 } & \multicolumn{1}{|c|}{$\mathrm{B}$} & Std Error & & & & \\
\hline DER <--- ROA & -2.148 & .946 & -.240 & -2.269 & .026 & Signifikan \\
\hline DER <--- CR & -.211 & .044 & -.512 & -4.837 & .000 & Signifikan \\
\hline DER <--- AG & .641 & .495 & .111 & 1.295 & .199 & Tidak Signifikan \\
\hline DER <-- SG & .046 & .737 & .005 & .063 & .950 & Tidak Signifikan \\
\hline ETR <--- DER & -.026 & .006 & -.477 & -4.177 & .000 & Signifikan \\
\hline ETR <--- ROA & -.109 & .049 & -.262 & -.262 & .031 & Signifikan \\
\hline ETR <-- SG & .111 & .050 & .247 & .247 & .031 & Signifikan \\
\hline
\end{tabular}

Sumber: Data sekunder diolah, 2017

Persamaan structural adalah:

$Y_{1}=1.355-2.148 X_{1}-0.211 X_{2}+0.641 X_{3}+0.046 X_{4}$

$Y_{2}=0.267-0.109 X_{1}+0.111 X_{4}-0.026 Y_{1}$

Keterangan :

$\mathrm{X}_{1}=$ Return on Asset $(\mathrm{ROA})$,

$\mathrm{X}_{2} \quad=$ Curent Ratio $(\mathrm{CR})$

$\mathrm{X}_{3} \quad=$ Asset Growth (AG),

$\mathrm{X}_{4} \quad=$ Sales Growth (SG),

$\mathrm{Y}_{1} \quad=$ Debt to Equity Ratio (DER)

$\mathrm{Y}_{2} \quad=$ Effective Tax Rate (ETR)

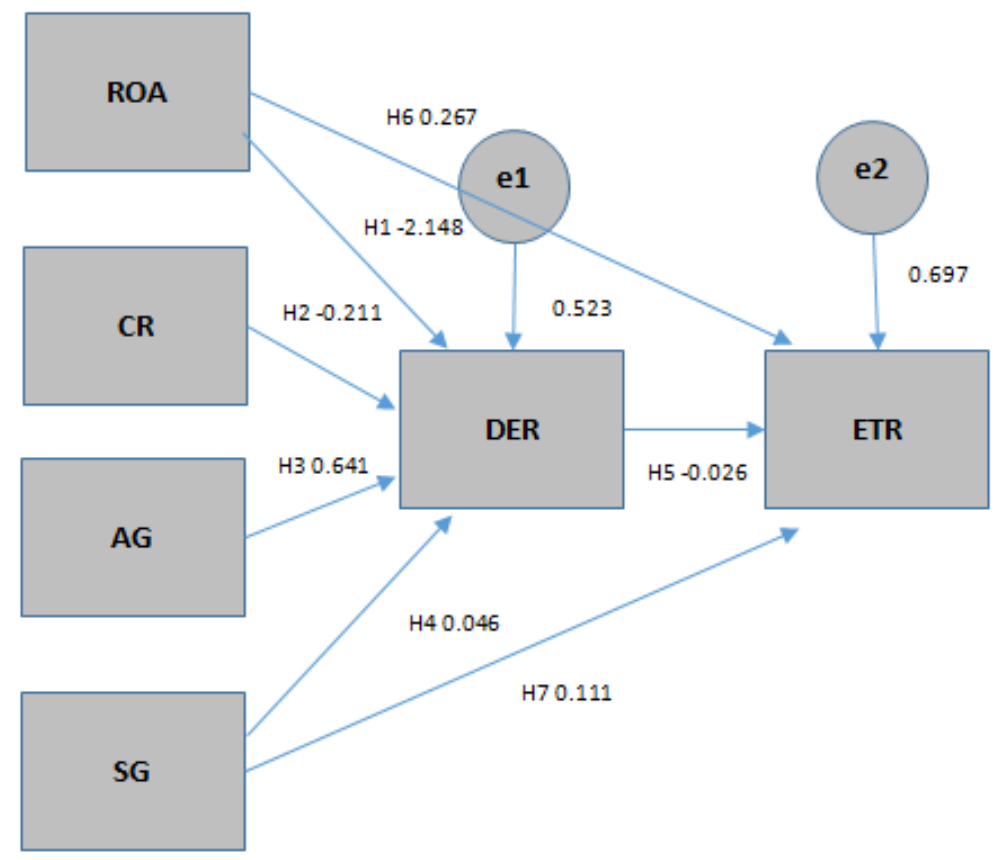

Gambar 1.2

Analisis Jalur (Path Analysis) 


\section{Pengujian Hipotesis}

\section{Pengujian Hipotesis 1}

Pengujian variabel ROA terhadap DER menghasilkan nilai $t$ hitung sebesar $2.269>t_{\text {tabel }}-1.983$ atau signifikansi $0.026<(0.05)$, maka daerah $\mathrm{H}_{0}$ ditolak dan Ha diterima. Hasil uji hipotesis menyatakan bahwa ROA berpengaruh signifikan terhadap DER dan memiliki hubungan negatif yang artinya apabila ROA meningkat maka DER akan mengalami penurunan. Perusahaan yang meningkat keuntungannya maka akan menggunakan pertambahan labanya untuk kepentingan investasi daripada menggunakan modal pinjaman dari pihak eksternal.

\section{Pengujian Hipotesis 2}

Pengujian variabel CR terhadap DER menghasilkan nilai $t$ hitung sebesar $4.837>t$ tabel -1.983 atau signifikansi $0.000<(0.05)$, maka daerah $\mathrm{H}_{0}$ ditolak dan Ha diterima. Hasil uji hipotesis menyatakan bahwa CR berpengaruh signifikan terhadap DER dan memiliki hubungan negatif yang artinya apabila CR meningkat maka DER akan mengalami penurunan. Perusahaan yang memiliki likuiditas tinggi menandakan bahwa perusahaan tersebut dapat menggunakan asset yang likuid sebagai sumber pembiayaan perusahaan.

\section{Pengujian Hipotesis 3}

Pengujian variabel AG terhadap DER menghasilkan nilai $t$ hitung sebesar 1.295 $<t$ tabel 1.983 atau signifikansi $0.199>(0.05)$, maka daerah $\mathrm{H}_{0}$ diterima dan $\mathrm{Ha}$ ditolak. Hasil uji hipotesis menyatakan bahwa AG tidak berpengaruh signifikan terhadap DER dan memiliki hubungan positif yang artinya apabila AG meningkat maka DER akan mengalami peningkatan. Perusahaan dengan asset yang meningkat maka akan meningkatkan kepercayaan pihak luar (kreditur) terhadap perusahaan, maka proporsi utang akan semakin besar daripada modal sendiri. Hal ini menunjukan perusahaan manufaktur yang terdapat di BEI tahun 2014-2016 telah mempunyai AG yang sebagaimana mestinya. Namun dalam hal ini AG tidak dapat dijadikan tolak ukur atau patokan dalam mengukur DER.

\section{Pengujian Hipotesis 4}

Pengujian variabel SG terhadap DER menghasilkan nilai $t$ hitung sebesar 0.063 $<t$ tabel 1.983 atau signifikansi $0.950>(0.05)$, maka daerah $\mathrm{H}_{0}$ diterima dan $\mathrm{Ha}$ ditolak, yaitu SG tidak berpengaruh signifikan terhadap DER. Hal ini menunjukan perusahaan manufaktur yang terdapat di BEI tahun 2014-2016 telah mempunyai SG yang sebagaimana mestinya. Namun dalam hal ini SG tidak dapat dijadikan tolak ukur atau patokan dalam mengukur DER. Karena memang pada hasil data SG tidak mempengaruhi perubahan DER dalam menentukan peningkatan perusahaan.

\section{Pengujian hipotesis 5}

Pengujian variabel DER terhadap ETR menghasilkan nilai $t$ hitung sebesar $4.177>t$ tabel -1.983 atau signifikansi $0.000<(0.05)$, maka daerah $\mathrm{H}_{0}$ ditolak dan Ha diterima, yaitu DER berpengaruh signifikan terhadap ETR. Hal ini 
menunjukkan bahwa perusahaan manufaktur yang terdaftar di BEI tahun 2014 2016 memiliki kemampuan dalam menutupi utang jangka panjang dan utang jangka pendek. Hubungan yang negatif menunjukan bahwa penggunaan utang pada perusahaan manufaktur yang terdaftar di BEI tahun 2014-2016 dalam membiayai kegiatan perusahaan terbukti menurunkan tarif pajak efektifnya dikarenakan terdapat biaya utang sebagai pengurang laba perusahaan.

\section{Pengujian hipotesis 6}

Pengujian variabel ROA terhadap ETR menghasilkan nilai $t$ hitung sebesar $2.213>t_{\text {tabel }}-1.983$ atau signifikansi $0.031<(0.05)$, maka daerah $\mathrm{H}_{0}$ ditolak dan $\mathrm{Ha}$ diterima, yaitu ROA berpengaruh signifikan terhadap ETR. Hal ini menunjukkan bahwa perusahaan manufaktur yang terdaftar di BEI tahun 2014-2016 memiliki Return on Asset (ROA) seperti yang telah berjalan dengan sebagaimana mestinya, apabila ROA meningkat, maka ETR akan mengalami peningkatan.

\section{Pengujian Hipotesis 7}

Pengujian variabel SG terhadap ETR menghasilkan nilai $t$ hitung sebesar -2.205 $>t$ tabel 1.983 atau signifikansi $0.031<(0.05)$, maka daerah $\mathrm{H}_{0}$ ditolak dan $\mathrm{Ha}$ diterima, yaitu SG berpengaruh signifikan terhadap ETR. Hal ini menunjukkan bahwa perusahaan manufaktur yang terdaftar di BEI tahun 2014-2016 memiliki Sales Growth (SG) seperti yang telah berjalan dengan sebagaimana mestinya, apabila SG meningkat maka ETR akan mengalami peningkatan.

\section{PEMBAHASAN}

\section{PENGARUH RETURN ON ASSET (ROA) TERHADAP DEBT TO EQUITY RATIO (DER)}

Return on Asset (ROA) merupakan rasio profitabilitas yang digunakan untuk mengukur efektifitas perusahaan dalam menghasilkan keuntungan dengan memanfaatkan aset yang dimilikinya. Hasil penelitian ROA berpengaruh signifikan terhadap DER. Hal ini mendukung penelitian yang dilakukan oleh Indah Respitasari (2015) bahwa ROA berpengaruh signifikan terhadap DER. Hal ini menunjukkan bahwa perusahaan manufaktur yang terdaftar di BEI tahun 2014-2016 memiliki Return on Asset (ROA) seperti yang telah berjalan dengan sebagaimana mestinya. Semakin tinggi perusahaan mempunyai ROA maka semakin tinggi kemampuan perusahaan dalam membayar kewajibannya baik jangka pendek maupun jangka panjang.

\section{PENGARUH CURENT RATIO (CR) TERHADAP DEBT TO EQUITY RATIO (DER)}

Rasio Likuiditas (Curent Ratio) digunakan untuk mengukur kemampuan perusahaan untuk memenuhi kewajiban jangka pendeknya dengan sumber daya yang tersedia untuk memenuhi kewajiban tersebut (Van Horne dan Wachowicz, 2001). Hasil penelitian Curent Ratio (CR) berpengaruh signifikan terhadap DER.

Hasil penelitian ini mendukung penelitian yang dilakukan oleh Sarsa Meta Nugrahani (2012) dan Dwi Ema Putra (2012) bahwa Curent Ratio (CR) berpengaruh signifikan terhadap DER. Hal ini menunjukkan bahwa perusahaan manufaktur yang terdaftar di BEI tahun 2014-2016 memiliki Curent Ratio (CR) yang menunjukkan 
perusahaan likuid. Semakin tinggi perusahaan mempunyai Curent Ratio (CR) yang tinggi maka semakin tinggi kemampuan perusahaan dalam memenuhi kewajibannya.

\section{PENGARUH ASSET GROWTH (AG) TERHADAP DEBT TO EQUITY RATIO (DER)}

Asset Growth (AG) menurut Sartono dalam penelitian Luluk (2016) menyatakan bahwa semakin cepat pertumbuhan perusahaan maka semakin besar kebutuhan dana untuk pembiayaan ekspansi. Hasil penelitian Asset Growth (AG) tidak berpengaruh signifikan terhadap DER.

Hasil penelitian ini mendukung penelitian yang dilakukan Indah Respitasari (2015) bahwa Asset Growth (AG) tidak berpengaruh signifikan terhadap DER. Hal ini perusahaan manufaktur yang terdapat di BEI tahun 2014-2016 telah mempunyai Asset Growth (AG) yang sebagaimana mestinya. Namun dalam hal ini Asset Growth (AG) tidak dapat dijadikan tolak ukur atau patokan dalam mengukur DER. Karena memang pada hasil data AG tidak mempengaruhi perubahan DER dalam menentukan kebijakan perusahaan.

\section{PENGARUH SALES GROWTH (SG) TERHADAP DEBT TO EQUITY RATIO (DER)}

Menurut Kasmir (2008) rasio pertumbuhan merupakan rasio yang menggambarkan kemampuan perusahaan dalam mempertahankan posisi ekonominya di tengah pertumbuhan perekonomian dan sektor usahanya. Hasil penelitian Sales Growth (SG) tidak berpengaruh signifikan terhadap DER.

Hasil penelitian ini mendukung penelitian yang dilakukan oleh Indah Respitasari (2015) dan Sarsa Meta Nugrahani (2012) bahwa Sales Growth (SG) tidak berpengaruh signifikan terhadap DER. Hal ini perusahaan manufaktur yang terdapat di BEI tahun 2014-2016 telah mempunyai Sales Growth (SG) yang sebagaimana mestinya. Namun dalam hal ini Sales Growth (SG) tidak dapat dijadikan tolak ukur atau patokan dalam mengukur DER. Karena memang pada hasil data Sales Growth (SG) tidak mempengaruhi perubahan DER dalam menentukan kebijakan perusahaan.

\section{PENGARUH DEBT TO EQUITY RATIO (DER) TERHADAP EFFECTIVE TAX RATE (ETR)}

Debt to Equity Ratio (DER) digunakan untuk mengukur kemampuan perusahaan dalam menutupi sebagian atau seluruh utang-utangnya baik jangka panjang maupun jangka pendek dengan dana yang berasal dari total modal dibandingkan dengan besarnya jumlah utang perusahaan tersebut (Hantono, 2015). Hasil penelitian ini adalah Debt to Equity Ratio (DER) berpengaruh signifikan terhadap Effective Tax Rate (ETR).

Hasil penelitian ini mendukung penelitian yang dilakukan oleh Eva Musyarrofah (2017) dan Scania Evana Putri (2016) bahwa Debt to Equity Ratio (DER) berpengaruh signifikan terhadap Effective Tax Rate (ETR). Hal ini menunjukkan bahwa perusahaan manufaktur yang terdaftar di BEI tahun 2014-2016 menutupi pembiayaan perusahaan dengan melakukan utang, dengan pertimbangan jika utang bertambah maka bertambah pula biaya bunga yang mengakibatkan laba bersih berkurang. Berkurangnya laba bersih menyebabkan menurunnya pajak yang dibayarkan oleh Perusahaan sehingga tarif pajak efektifnya menjadi lebih kecil. 


\section{PENGARUH RETURN ON ASSET (ROA) TERHADAP EFFECTIVE TAX RATE (ETR)}

Return on asset (ROA) merupakan rasio yang menggambarkan kemampuan perusahaan untuk menghasilkan laba dengan menggunakan aset yang dimiliki. Aset suatu perusahaan didanai oleh pemegang saham dan kreditur sehingga aset tersebut akan menjadi modal kerja bagi perusahaan dalam menjalankan usahanya. Perusahaan yang memiliki kemampuan untuk memperoleh laba yang tinggi harus mempersiapkan pajak yang akan dibayarkan sebesar persentase tertentu yang telah ditetapkan dari laba yang diperoleh (Putri, 2016).

Hasil penelitian adalah Return on asset (ROA) berpengaruh signifikan terhadap Effective Tax Rate (ETR). Hasil penelitian ini mendukung penelitian yang dilakukan oleh Indah Respitasari (2015), Sabli dan Noor (2012) membuktikan bahwa Return on asset (ROA) berpengaruh signifikan terhadap Effective Tax Rate (ETR). Hal ini menunjukkan bahwa perusahaan manufaktur yang terdaftar di BEI tahun 2014-2016 memiliki Return on Asset (ROA) seperti yang telah berjalan dengan sebagaimana mestinya. Semakin tinggi perusahaan mempunyai Return on asset (ROA) maka semakin tinggi kemampuan perusahaan dalam membayar pajak.

\section{PENGARUH SALES GROWTH (SG) TERHADAP EFFECTIVE TAX RATE (ETR)}

Perusahaan dengan tingkat pertumbuhan penjualan yang tinggi maka akan memperoleh laba yang juga tinggi. Pertumbuhan penjualan yang tinggi akan selalu diikuti peningkatan laba yang menyebabkan meningkat pula tarif pajak efektifnya (Nugrahani, 2012). Pertumbuhan penjualan akan menyebabkan laba bersih semakin besar. Dari laba usaha yang meningkat pada akhirnya akan meningkatkan pula tarif pajak efektifnya.

Hasil penelitian adalah Sales Growth (SG) berpengaruh signifikan terhadap Effective Tax Rate (ETR). Hal ini menunjukkan bahwa perusahaan manufaktur yang terdaftar di BEI tahun 2014-2016 memiliki Sales Growth (SG) yang menunjukkan perusahaan mempunyai pertumbuhan penjualan yang tinggi, semakin tinggi perusahaan mempunyai pertumbuhan penjualan maka semakin tinggi kemampuan perusahaan dalam membayar pajak.

\section{PENUTUP}

Penelitian ini menganalisis pengaruh profitabilitas yang diproksikan dengan Return on Asset (ROA), pengaruh likuiditas yang diproksikan dengan Curent Ratio (CR) dan pertumbuhan perusahaan yang diproksikan dengan pertumbuhan asset (AG) dan pertumbuhan penjualan (SG) terhadap Effective Tax Rate (ETR) dengan variabel intervening Debt to Equity Ratio (DER).

Hasil penelitian adalah Return on Asset (ROA) berpengaruh negatif signifikan terhadap Debt to Equity Ratio (DER), artinya apabila ROA meningkat maka DER atau leverage akan mengalami penurunan, Curent Ratio (CR) berpengaruh negatif signifikan terhadap Debt to Equity Ratio (DER), artinya bahwa apabila Curent Ratio (CR) meningkat maka utang perusahaan akan terjadi penurunan, Asset Growth (AG) berpengaruh positif tidak signifikan variabel Debt to Equity Ratio (DER), artinya bahwa apabila aktiva meningkat maka utang perusahaan akan meningkat pula, Sales Growth (SG) berpengaruh positif tidak signifikan terhadap Debt to Equity Ratio yang artinya 
dengan meningkatnya pertumbuhan penjualan akan meningkatkan jumlah kewajiban perusahaan, Debt to Equity Ratio (DER) berpengaruh negatif signifikan terhadap Effective Tax Rate (ETR) yang artinya jika jumlah utang perusahaan meningkat maka akan berpengaruh terhadap penurunan tarif pajak efektifnya, Return on Asset (ROA) berpengaruh positif signifikan terhadap Effective Tax Rate (ETR). Hal ini menunjukkan bahwa semakin tinggi perusahaan mempunyai Return on asset (ROA) maka semakin tinggi kemampuan perusahaan dalam membayar pajak dan Sales Growth (SG) berpengaruh positif signifikan terhadap Effective Tax Rate (ETR) artinya semakin tinggi perusahaan mempunyai pertumbuhan penjualan maka semakin tinggi kemampuan perusahaan dalam membayar pajak.

\section{Implikasi Manajerial}

Berdasarkan hasil uji statistik atas data sekunder yang telah dilakukan, maka implikasi manajerial yang bisa dilakukan adalah manajemen perusahaan, diharapkan dengan makin ketatnya peraturan perpajakan yang ada dan tuntutan besarnya peran warga negara dalam pembiayaan pembangunan nasional, tidak melakukan praktekpraktek penghindaran pajak dan penggelapan pajak, dengan melakukan pencatatan dan pembuatan laporan keuangan secara wajar serta pemenuhan kewajibannya perpajakan sesuai Undang-undang perpajakan yang berlaku yaitu menghitung, menyetor dan melaporkan kewajiban perpajakannya dengan benar dan Perusahaan yang mengalami laju pertumbuhan yang bagus dapat memilih menggunakan dana eksternal (utang) dibanding dana internal yang dimilikinya untuk mengembangkan perusahaannya, asalkan pengambilan utang dimaksud dilakukan secara layak dengan mempertimbangkan tingkat likuiditas perusahaan.

\section{Keterbatasan Penelitian}

Keterbatasan pada penelitian ini adalah tidak dapat membuktikan pengaruh Asset Growth terhadap Debt to Equity Ratio, hal ini menunjukan bahwa Asset Growth pada perusahaan manufaktur yang terdapat di BEI Tahun 2014 -2016 tidak dapat dijadikan tolak ukur dalam mengukur Debt to Equity Ratio. Dalam penelitian ini juga tidak berhasil membuktikan pengaruh Sales Growth terhadap Debt to Equity Ratio, hal ini menunjukan bahwa Sales Growth pada perusahaan manufaktur yang terdapat di BEI Tahun 2014 -2016 tidak dapat dijadikan tolak ukur dalam mengukur debt to equity ratio dan kecilnya koefisien determinasi atau $\mathrm{R}^{2}$ pada Effective Tax Rate yang menunjukkan bahwa variabilitas Effective Tax Rate yang dapat dijelaskan oleh variabilitas Return on Asset, Curent Ratio, Asset Growth, Sales Growth dan Debt to Equity Ratio hanya sebesar 0.079. Ini menandakan masih besarnya pengaruh variabel lainnya yang belum diteliti dan kemungkinan tidak hanya dari analisis fundamental atas laporan keuangan yang ada. 


\section{DAFTAR PUSTAKA}

Ang, Robert, 1997, Buku Pintar Pasar Modal Indonesia. Jakarta : Media Staff Indonesia.

Ardyansah, Danis, 2014, Pengaruh Size, Leverage, Profitability, Capital Intensity Ratio dan Komisaris Independen terhadap Effective Tax Rate (ETR), Universitas Diponegoro, Semarang.

Brigham, Eugene.F dan Joel F Houston, 2001, Manajemen Keuangan. Edisi Kedelapan Buku 2. Jakarta : Erlangga.

Desi, Handayani, 2014, Pengaruh Transaksi Perusahaan Afiliasi Terhadap Tarif Pajak Efektif, Politeknik Caltex, Riau.

Hanum, Hashemi Rodian 2013, Pengaruh Karakteristik Corporate Governance terhadap Effective Tax Rate, Universitas Diponegoro, Semarang.

Hantono, 2015, Pengaruh Curent Ratio dan Debt To Equity Ratio Terhadap Profitabilitas Pada Perusahaan Manufaktur Sektor Logam dan Sejenisnya yang Terdaftar di Bursa Efek Indonesia Periode 2009 - 2013, Universitas Prima Indonesia.

Karayan, John E dan Charles W. Swenson, 2007, Strategic Business Tax Planning, New Jersey, John Wiley \& Sons.

Kesuma, Ali, 2009, Analisis Faktor yang Mempengaruhi Struktur Modal Serta Pengaruhnya terhadap Harga Saham Perusahaan Real Estate yang Go Public di Bursa Efek Indonesia, Universitas Darwan Ali Sampit, Kalimantan Tengah.

Luluk, Mariyah, 2016. Pengaruh Kinerja Keuangan, Asset Growth dan Firm Size Terhadap Dividend Payout Ratio. Jurnal Ilmu dan Riset Manajemen : Volume 5 Nomor, Mei 2016:4.

Mayangsari, Sekar, 2001. Analisis Faktor-faktor yang Mempengaruhi Keputusan Pendanaan Perusahaan : Pengujian Pecking Order Hypothesis. Media Riset Akuntansi, Auditing dan Informasi, Vol 1 No. 3:1-26.

Musyarrofah, Eva, 2017, Pengaruh Kepemilikan Manajerial, Leverage dan Size Terhadap Cash Effective Rate, Sekolah Tinggi Ilmu Ekonomi Indonesia (STIESIA), Surabaya.

Modigliani, F dan Miller H, 1968, The Cost of Capital, Corporation Finance and Theory of Investment, Journal American Economic Review, 48.

Natalia, Putri, 2012, Analisis Faktor-Faktor yang Mempengaruhi Pengungkapan Corporate Governance Pada laporan Tahunan. Universitas Diponegoro, Semarang.

Nugrahani, Sarsa Meta 2012, Analisis Pengaruh Profitabilitas, Likuiditas, Pertumbuhan Penjualan, Ukuran Perusahaan dan Kepemilikan Manajerial terhadap Struktur Modal, Universitas Diponegoro, Semarang.

Pandey, I, M, 2003, Capital Structure and Market Power Interaction : Evidence from Malaysia, in Zamri Ahmad, Ruhani Ali, Subramaniam Pillay. Proceedings for the fourth annual Malaysian Finance Association Symposium. Penang. Malaysia.

Putri, Scania Evana 2016, Pengaruh Ukuran Perusahaan, ROA, Leverage dan Intensitas Modal terhadap Tarif Pajak Efektif, Universitas Riau, Pekanbaru

Putra, Dwi Ema, 2012, Pengaruh Profitabilitas, Likuiditas, Ukuran, Pertumbuhan terhadap Struktur Modal Industri Otomotif di BEI, Universitas Udayana, Bali. 
Respitasari, Indah, 2015. Analisis Pengaruh Return On Asset, Asset Growth dan Sales Growth Terhadap Debt To Equity Ratio Serta Dampaknya Terhadap Effektive Tax Rate, Universitas Semarang, Semarang.

Richardson, Grant, and Lanis, Roman, 2007, Determinants of The Variability in Corporate Effective Tax Rates and Tax Reform : Evidence from Australia, Journal of Accounting and Public Policy, 689-704.

Riyanto, Bambang, 2001. Dasar dasar Pembelanjaan Perusahaan. BPFE, Yogyakarta.

Roifah, Nimatur, 2015, Pengaruh Leverage dan Capital Intensity Ratio Terhadap Effective Tax Rate : Dimoderasi oleh Profitability, Universitas Riau, Pekanbaru.

Rodriguez and Arias, 2013. Do Business Characteristics Determine an Effective Tax Rate?. The Chinese Economy, 45 (6), 60-83.

Ryan, Wilson et.al, 2014, How Quickly Do Firms to Target Levels of Tax Avoidance?, University of Oregon, United State.

Swingly, Calvin, 2015, Pengaruh Karakter Eksekutif, Komite Audit, Ukuran Perusahaan, Leverage dan Sales Growth pada Tax Avoidance, Jurnal Akuntansi Universitas Udayana, Bali.

Sunarwi, 2010, Analisis Faktor-faktor yang Mempengaruhi Struktur Modal serta Dampak Struktur Modal terhadap Return Saham Perusahaan Manufaktur yang Terdaftar di BEI Periode 2006-2008, Universitas Diponegoro, Semarang.

Sabli, Nurshamimi dan Noor, 2012, Tax Planning and Corporate Governance. Proceeding International Conference on Business and Economic Research. Bandung.

Teddy, Chandra, 2008, Pengaruh Profitabilitas Aktiva Terhadap Kinerja Keuangan dan Nilai Perusahaan, Pelita Indonesia School of Business. Jakarta.

Van Horne, James and Wachowicz, John, 2001, Fundamentals of Financial Management, Mishawaka, U.S.A. 